\title{
THE COL-GULLY AND GLACIAL DEPOSITS AT COURT HILL, CLEVEDON, NEAR BRISTOL, ENGLAND
}

\author{
By D. D. Gilbertson \\ (Department of Prehistory and Archaeology, University of Sheffield, Sheffield Sio 2TN, \\ England)
}

and A. B. Hawkins

(Department of Geology, University of Bristol, Bristol BS8 ITR, England)

Abstract. An outline is given of the Quaternary geology and geomorphology of Court Hill Col in Failand Ridge near Glevedon, Avon County, from observations made during the construction of the $\mathrm{M}_{5}$ Motorway.

A glacial col-gully about $100 \mathrm{~m}$ wide and approximately $25 \mathrm{~m}$ deep is described. The col-gully, eroded through the Carboniferous Limestone, opens and deepens northward. Associated with the Col and the col-gully is a complex sequence of Quaternary deposits. Uppermost in the sequence is a layer of red sandy silt (cover sand) approximately $0.5 \mathrm{~m}$ thick, of periglacial origin, probably of Devensian (Weichselian) age. Largely confined to the col-gully are unstratified tills, stratified ice-contact deposits and glaciolacustrine del taic deposits. The glaciogenic deposits are up to $25 \mathrm{~m}$ thick. Boulders of about $8 \mathrm{Mg}$ in weight have been observed.

The geomorphology of the col-gully, and the stratification and composition of the glaciogenic deposits, demonstrate that an ice sheet at least $85 \mathrm{~m}$ thick had impinged against the south flank of Failand Ridge and was discharging immense quantities of water and sediment down an ice-contact slope through the Col into a small ice-marginal lake north of the col-gully. The ice sheet is regarded as being Wolstonian, or Anglian, in age.

The precise origins of the col-gully and the interpretation of the glacial sequence are not yet completely clear. However, it is believed that the balance of evidence indicates that both the col-gully itself and the glaciogenic deposits represent a complex sub-, en- and pro-glacial sequence associated with the downwasting and division of an ice mass into two parts by the "emergence" of Failand Ridge. The possible extent and geomorphological implications of ice-sheet penetration into the Bristol area are briefly discussed.

Résumś. Les dépôts glaciaires et torrentiels de Court Hill, Clevedon, près de Bristol, Angleterre. On donne un aperçu de la géologie et de la géomorphologie du quaternaire du Court Hill Col dans la Failand Ridge près de Clevedon, Avon County, à partir d'observations réalisées durant la construction de l'autoroute $\mathrm{M}_{5}$.

Un défilé glaciaire d'environ $100 \mathrm{~m}$ de large et approximativement $25 \mathrm{~m}$ de profondeur est décrit. Le défilé, creusé dans les calcaires du carbonifère, s'ouvre et s'approfondit vers le nord. Associée avec le Gol et le défilé, on trouve une séquence complexe de dépôts quaternaires. Au sommet de la séquence il y a un niveau de sables rouges limoneux (sables de couverture) épais d'environ $0,5 \mathrm{~m}$, d'origine périglaciaire d'âge probablement Devensian (Weichselian). Largement limitées au défilé sont des argiles morainiques non stratifiées, des dépôts stratifiés de contact à la glace et des dépôts déltaïques glacio-lacustres. Les dépôts d'origine glaciaire ont jusqu'à $25 \mathrm{~m}$ d'épaisseur. Des blocs d'environ $8 \mathrm{Mg}$ en poids ont été observés.

I a géomorphologie du défile, la stratification et la composition des dépôts d'origine glaciaire démontrent qu'une calotte glaciaire d'au moins $85 \mathrm{~m}$ d'épaisseur s'est bloquée contre le flanc sud de la Failand Ridge et débitait d'énormes quantités d'eau et de sédiments au bas d'une pente au contact avec la glace à travers le Col dans un petit lac pro-glaciaire au nord du défilé. On pense que la calotte est d'âge Wolstonian ou Anglien.

Les origines précises du défilé et l'interprétation de la séquence glaciaire ne sont pas encore complètement claires. Cependant, on pense que le bilan des preuves indique que tant le défilé lui-même que les dépôts d'origine glaciaire représentent une séquence complexe sub-, en- et pro-glaciaire associée à la destruction et à la division d'une masse de glace en deux tronçons par l" "émergence" de la Failand Ridge. On discute brièvement de l'cxtension possible et des implications géomorphologiques d'uné pénétration d'une calotte glaciaire dans le secteur de Bristol.

Zusammenfassung. Die rinnengebundenen und glazialen Ablagerungen am Court Hill, Clevedon nahe Bristol in England. Die Quartär-Geologic und-Geomorphologie des Court Hill Col im Failand Ridge bei Clevedon, Avon County, wird auf der Grundlage von Beobachtungen beim Bau der Autobahn $\mathrm{M}_{5}$ dargelegt.

Eine glaziale Joch-Abflussrinne von etwa $100 \mathrm{~m}$ Breite und annähernd $25 \mathrm{~m}$ Tiefe wird beschrieben. Die Rinne führt durch Karbonischen Kalkstein und verläuft unter Eintiefung nordwärts. Verbunden mit dem Joch und der Rinne ist eine komplizierte Folge quartärer Ablagerungen. Zuoberst in der Folge findet. sich eine etwa $0,5 \mathrm{~m}$ dicke Schicht aus rotem, verschlammtem Sand (Decksand) periglazialen Ursprungs, vermutlich aus der Devensian- (Weichsel-) Eiszeit. Im wesentlichen auf die Rirne beschränkt, folgen ungeschichtete Schotter, geschichtete Fisrand-Ablagerungen und deltaartige Aufschüttungen in einen Eisrandsee. Die glaziogenen Ablagerungen sind bis zu $25 \mathrm{~m}$ mächtig; sie enthalten Felsbrocken bis zu 8 Tonnen Gewicht. 


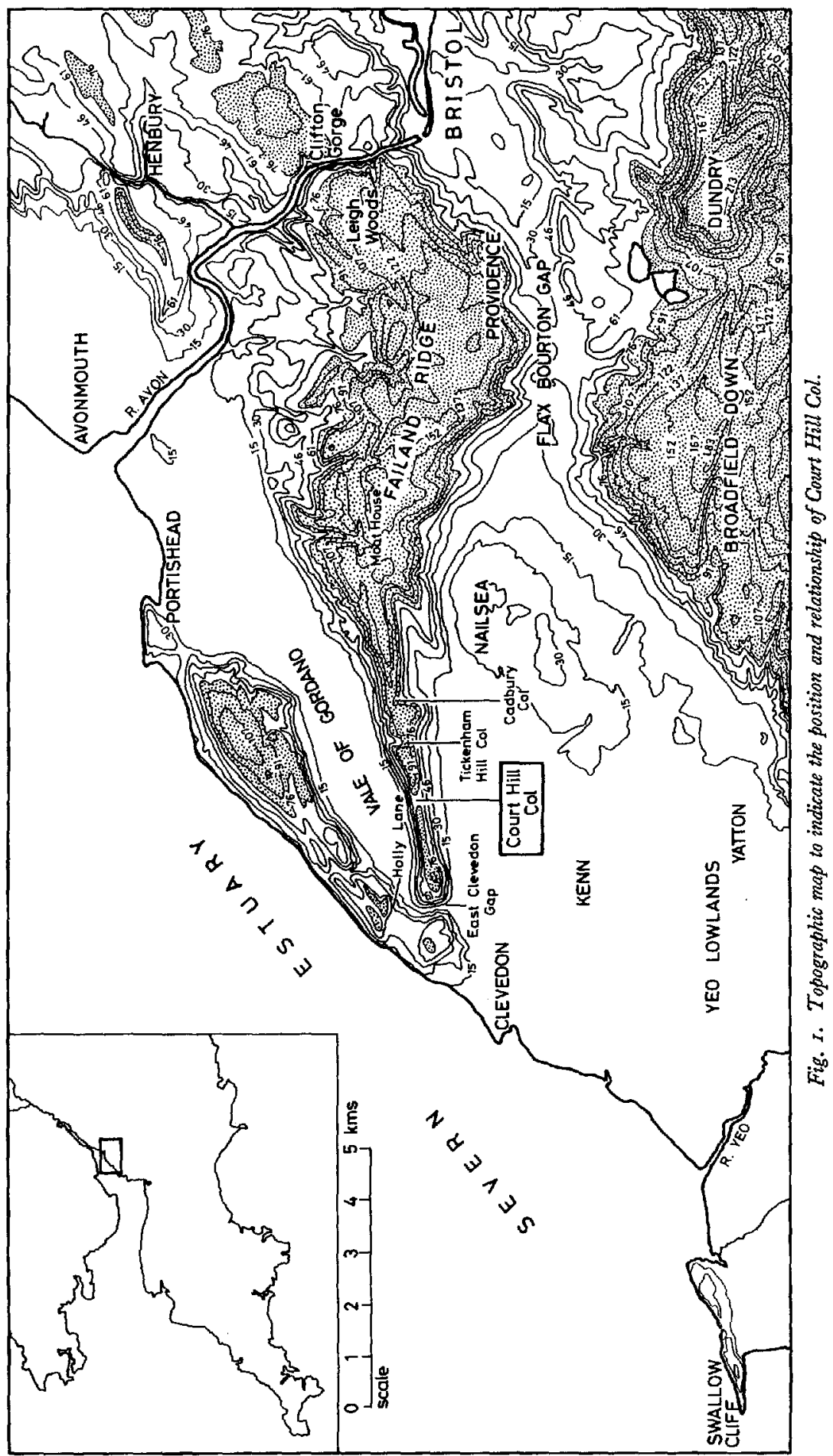


Die Geomorphologie der Abflussrinne und die Schichtung und Zusammensetzung der glaziogenen Ablagerungen lassen erkennen, dass eine Eisdecke von mindestens $85 \mathrm{~m}$ Dicke sich an die Südflanke des Failand Ridge herangeschoben hatte und riesige Mengen von Wasser und Schutt über einen Hang am Eisrand durch das Joch in einen kleinen Eisrandsee nördlich der Jochrinne ergoss. Die Eisdecke dürfte der Wolstonian- oder Anglian-Eiszeit angehört haben.

Der Ursprung der Jochrinne und die Deutung der glazialen Ablagerungsfolge bedürfen noch weiterer Untersuchungen. Doch lässt die Gesamtheit der Erscheinungen glaubhaft erkennen, dass sowohl die Jochrinne selbst wie die glaziogenen Ablagerungen ein kompliziertes sub-, in- und proglaziales System darstellen, das mit dem Verfall und der Spaltung einer Eismasse in zwei Teile durch den "Aufstieg" des Failand Ridge verbunden war. Das mögliche Ausmass und die gcomorphologischen Folgen des Vordringens der Eisdecke in das Gebiet von Bristol werden kurz diskutiert.

\section{INTRODUCTION}

Failand Ridge forms an area of high ground stretching from Clifton Gorge at Bristol in the east to the Severn Estuary at Glevedon (Fig. I). Principally, it is composed of Carboniferous Limestone. Three main cols occur in the western part of the ridge-Court Hill Col, Tickenham Hill Col and Cadbury Col. In addition, the ridge is completely breached by the steep-sided, deep through valley of East Clevedon Gap. (also known as "Swiss Valley").

In I853, Joshua Trimmer described the drift deposits he located in Norton's Wood (Fig. 2), probably at grid reference ST 437723. Trimmer concluded from the content of "nonlocal" rock types and the altitude of the deposits that they may represent a southern termination of the "glacial sea", then associated with what we now know as glaciation. Between $197^{\circ}$ and $197^{2}$, the drift observed by Trimmer was exposed during the construction of the M5 Motorway through the Col. The then available exposures at Court Hill, and other sites in the area, were demonstrated and described briefly by Hawkins and Kellaway (1971). These observations together with subsequent studies have led several authors to re-advance Harmer's (1907) much criticized hypothesis that Pleistocene ice sheets penetrated far into the coastal lowlands of what was then Somerset (since 1974 partly in Avon Gounty). The recent finds of glaciogenic deposits plus the current interpretations of geomorphological evidence do not necessarily agree in detail with those advanced by Harmer (Donovan, 1969; Hawkins and Kellaway, I971; Hawkins, 1972; Colbourne and others, 1974; Gilbertson and Hawkins, in press).

The present paper describes more fully and interprets the Quaternary deposits and landforms exposed in Court Hill Col, as observed during the construction of the $\mathrm{M}_{5}$ Motorway (Fig. 3). The Gol is significant for several reasons. First, it demonstrates the penetration of an ice sheet into a part of southern England which until $197^{\circ}$ had been considered by most

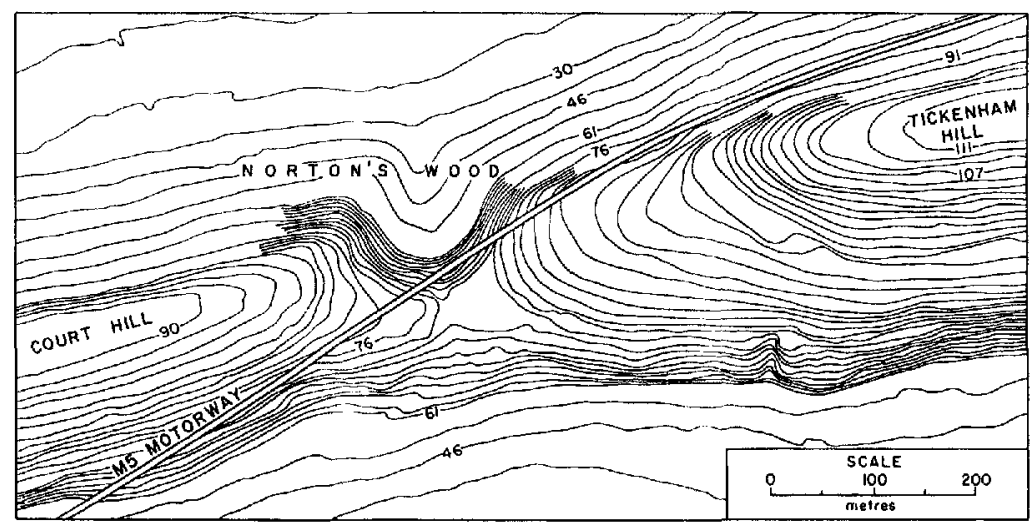

Fig. 2. Topography of Court Hill Col prior to the beginning of construction for the $M_{5}$ Motorway. Contour interval changes above $61 \mathrm{~m}$ 0.D. 
authors to be beyond the limit of glaciation. Secondly, it is an example in lowland Britain of the glacial landform originally described from Scandinavia by Mannerfelt (I945) as a sadelskar or col-gully. Further, the motorway excavations revealed in detail the internal structure of the glaciogenic deposits occupying the col-gully.

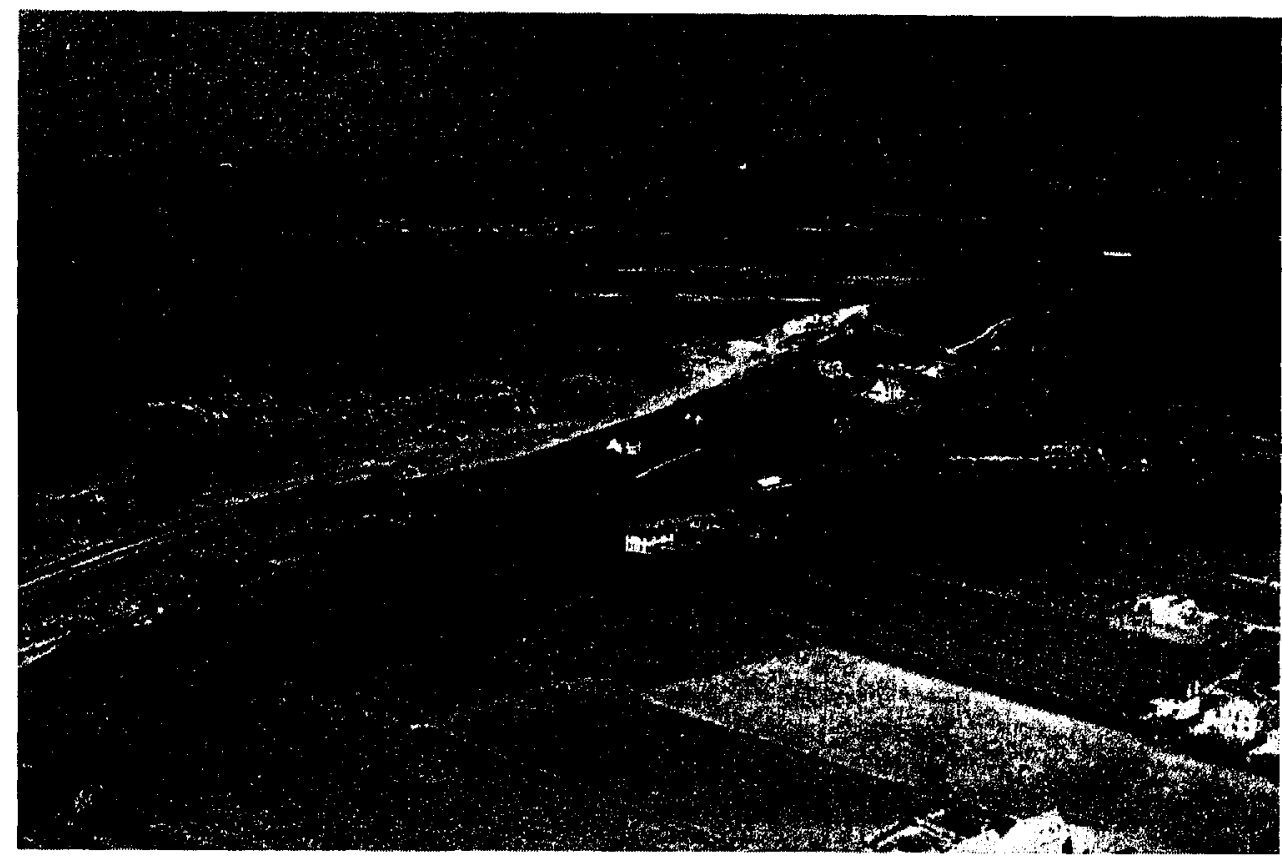

Fig. 3. Topographic setting of Court Hill Col.

As a result of slope grading and seeding, many details of the exposures studied during construction are now lost. It is, however, still possible to determine the col-gully walls from the bridle-path bridge over the motorway. Similarly, blocks of naturally cemented drift are still visible by the motorway boundary fence at Norton's Wood, and by the eastern foundations of the bridle-path bridge. Access to the main motorway cutting slopes is prohibited.

The stratigraphical nomenclature used here follows that recommended for description of the British Quaternary in Mitchell and others (1973).

\section{RELIEF AND GEOLOGY}

The surface relief of Court Hill Col, prior to the motorway construction, is shown in Fig. 2. The Col itself was $74 \mathrm{~m}$ O.D. and approximately $0.25 \mathrm{~km}$ wide, lying between Court Hill ( $9 \circ \mathrm{m}$ o.D.) to the west and Tickenham Hill ( I I $\mathrm{m}$ O.D.) on the east. Recent reference to the geology of this area was made in Hawkins and Kellaway (197I) and Hawkins (r972). The Col is eroded through the Black Rock Limestone and Dolomite of the Carboniferous Limestone Formation, dipping at about $35^{\circ}$ south. Here, the Carboniferous limestones are thrust over Coal Measures sandstones, which crop out on the north side of the Col. Dolomitic Conglomerate and Keuper Marl of the Triassic crop out south of the crest of the ridge. Both flanks are covered by a varying thickness of red sandy silt, initially mapped by Osmond as the Tickenham Soil Series and subsequently shown to be a cover sand of periglacial origin (Findlay, 1965; Gilbertson and Hawkins, in press; Vink, unpublished). 
The area of Court Hill Col was extensively investigated by drilling prior to the construction of the $\mathrm{M}_{5}$ Motorway. Particle-size analyses by Soil Mechanics Ltd (in I 967) revealed the presence of well to poorly sorted sand, gravel, and cobble layers overlying the Black Rock Dolomite. The distribution of this drift was mapped by Hawkins and Kellaway (1971, fig. 5). Their results, together with subsequent examination, have shown that the drift crops out from about 83 to $65 \mathrm{~m}$ o.D. on the south flank of the Col, while the lowest outcrop on the north flank, in Norton's Wood, is about $50 \mathrm{~m}$ o.D. The total east-west width of the drift, beneath the cover sands, is approximately $130 \mathrm{~m}$. The thickness of the drift beneath the cover sand varies, the great bulk of the drift being confined to the deep channel or gully-the col-gully-eroded into the Carboniferous Limestone bedrock. Up-slope of the main col-gully, the cobble- and boulder-rich deposits thin very rapidly.

\section{DESGRIPTION}

\section{Stratigraphy of Pleistocene deposits}

The thickness and stratigraphical position of the various deposits associated with the Col have been reconstructed from many temporary exposures. A composite section corresponding to the line of the central motorway reservation is illustrated in Figure 4 and described below.

Unit 6. Red sandy silt. This uppermost deposit covers both drift and bedrock to a depth up to $0.5 \mathrm{~m}$. These soils can be traced into the Tickenham Soil Series of Findlay (1965). Open solution joints in the Carboniferous Limestone are frequently infilled with sandy silt for a depth of several metres (probably re-deposited cover sand).

Unit 5. Red-brown gravel to boulder-rich diamicton. The deposit is unsorted and unbedded. Boulders with diameters up to $0.5 \mathrm{~m}$ are common. The matrix is a stiff red sandy silt. The thickness is variable but greatest near the eastern wall of the col-gully, where it reaches up to $3 \mathrm{~m}$.

Unit 4. Diamicton up to $0.75 \mathrm{~m}$ thick; comprising cobbles and boulders in a poorly bedded sandy silt matrix. This layer may be impersistent; the excavations did not permit this to be checked.

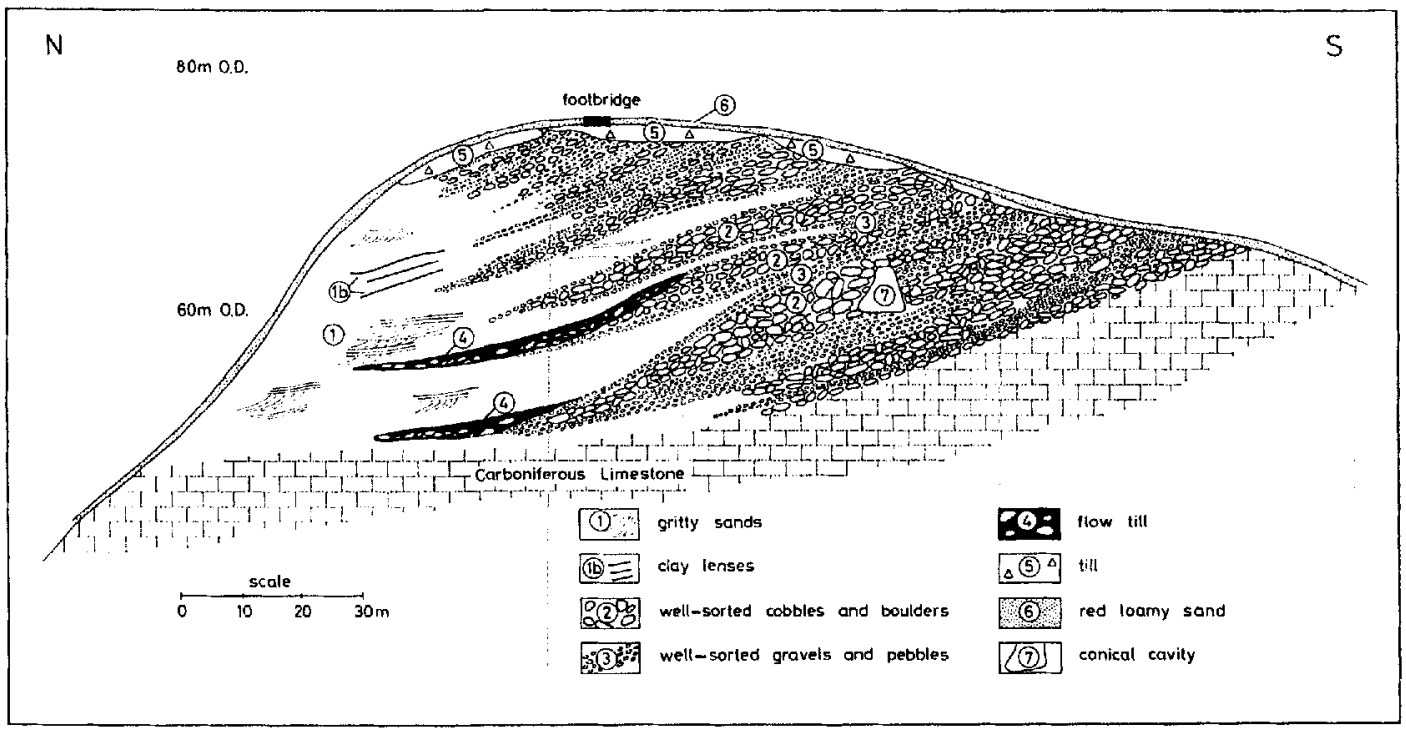

Fig. 4. Schematic section through the Quaternary deposits in Court Hill Col. 


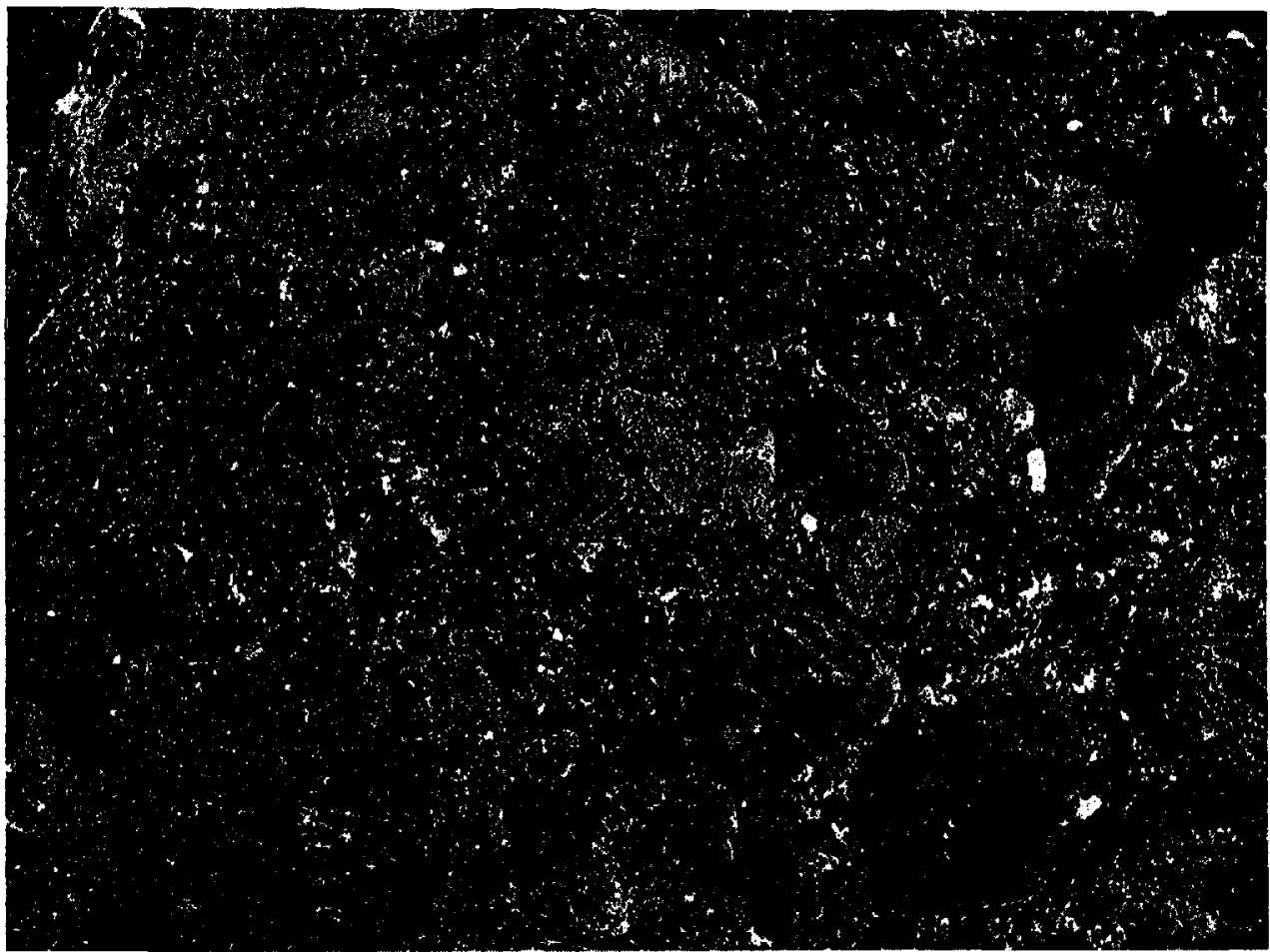

Fig. 5. Partially cemented (point contact) interbedded gravels with cobbles and boulders. The beds dip northward up to $34^{\circ}$.

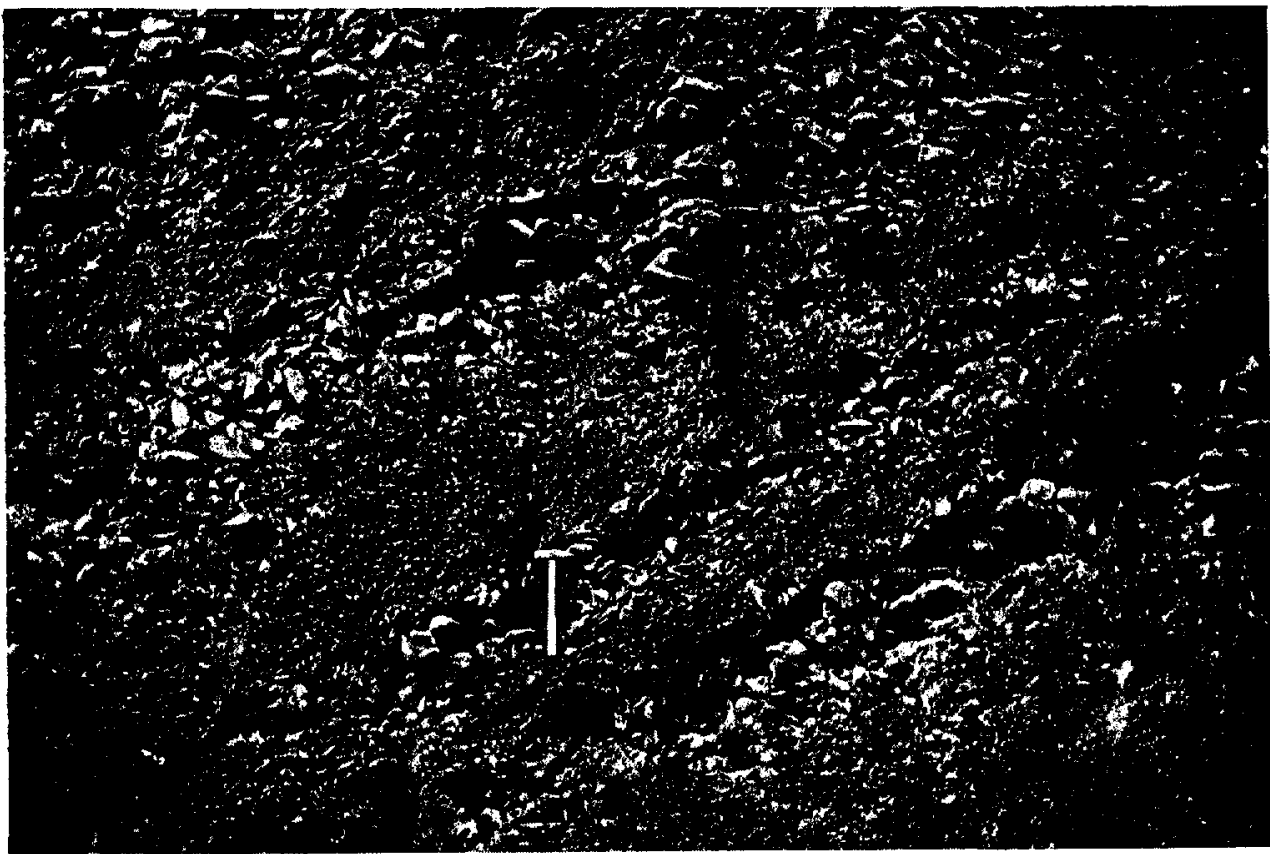

Fig. 6. Well-sorted gravels giving a more compact material. 
Unit 3. Gravel and cobble layers between 0.5 and $1.5 \mathrm{~m}$ thick; well-sorted, generally well-rounded, sometimes bedded and often grading smoothly upwards or downwards into unit 2. Calcareous cementation at point contact. In some cases more densely packed (Fig. 5).

Unit 2. Stratified gravel to boulder deposit, with rare silty sand matrix in the finer material. Generally well-sorted well-rounded clasts but in some horizons the clasts were less well sorted and rounded. In places calcareous cement binds the material; however, where there is little or no matrix, the clasts are cemented at point contact. Boulders up to $8 \mathrm{Mg}$ in weight have been observed. Large conical cavities occur measuring up to $2-3 \mathrm{~m}$ decp, I $\mathrm{m}$ wide at the top and 3-4 $\mathrm{m}$ at the base (unit 7 ). In the northern half of the section, the deposits could be seen to form $0.2-2 \mathrm{~m}$ bands of material dipping northward at $30-37^{\circ}$ (Fig. 6) through the Col, not parallel to the dip of the col-gully walls. unit 1 .

The deposits of unit 2 grade into those of units 3 and interdigitate with material of

Unit $I$. Coarse gritty sands interdigitating with the boulder-rich deposits in the northern half of the col-gully. The sands are markedly cross-laminated (Fig. 7). Occasionally, the sands are interspersed with thin clay/silt seams, always less than $20 \mathrm{~mm}$ in thickness (unit Ib).

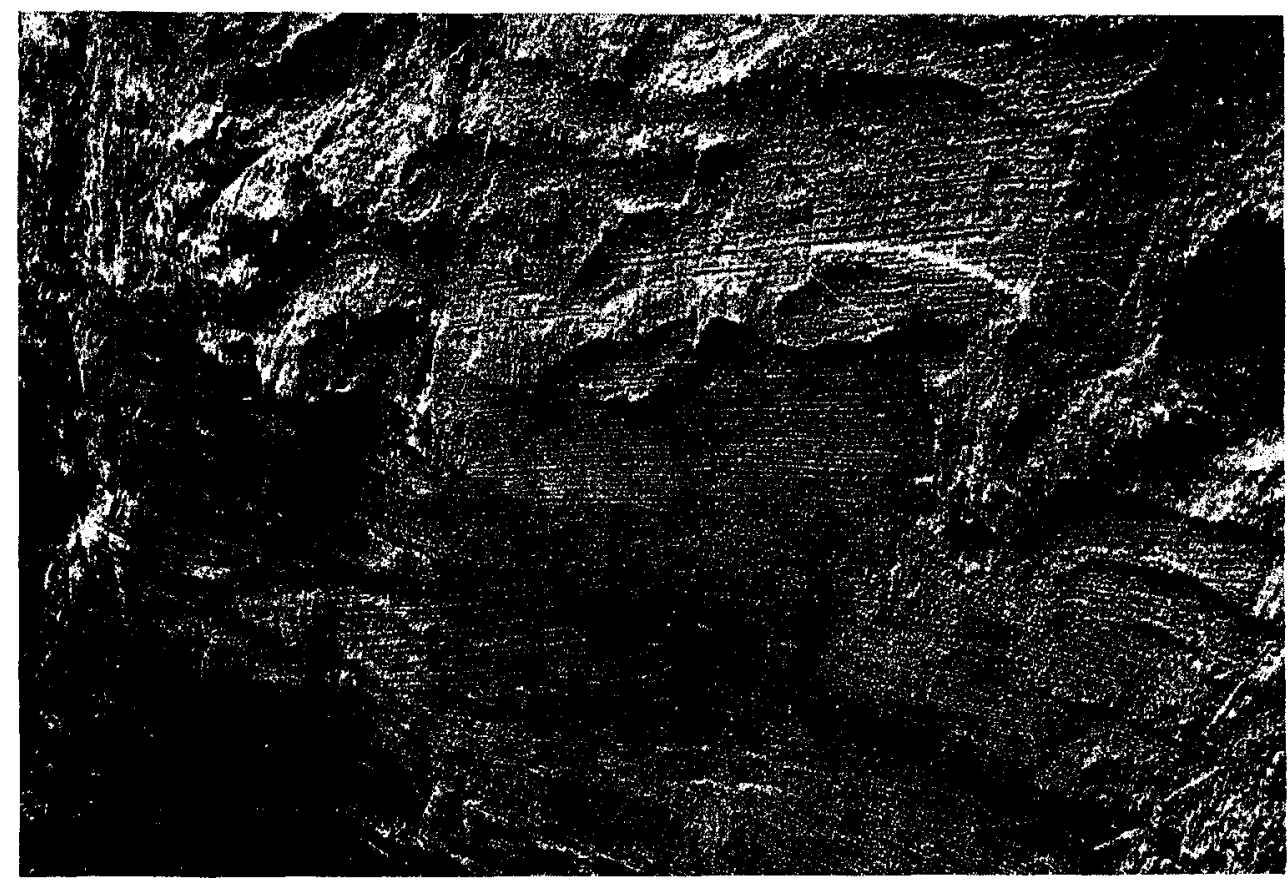

Fig. 7. Cross-bedded loose sands, as they occur "below" the main gravelly layer.

\section{Composition}

The gravel, cobble and boulder deposits are cemented at point contact by a calcareous deposit. Apart from unit 6, the composition of the main deposits is similar. The largest clasts and the most frequent rock type are Carboniferous Limestone. Other fairly common rock types were Pennant Sandstone (Carboniferous), chert (Carboniferous), yellow Triassic sandrock and irregular "lumps" of Keuper Marl (Triassic), and red Devonian sandstones. Also present are smaller quantities of Cretaceous Chalk flints and Cretaceous Greensand cherts. 
The sands of unit $\mathrm{I}$ yielded the following relic Jurassic and Cretaceous foraminiferal fauna, identified by Professor J. W. Murray: Marginulina, Frondicularia, Saracenaria, Citharina, Nodosaria, Hedbergella, Praeglobotruncana, Gyroidina, and Gumbitriella.

\section{The col-gully}

The detailed location and dimensions of the sub-drift col-gully are imperfectly known from direct observation and bore holes. Figure 8 shows the geology of the gully as determined from bore holes. As frequently with engineering schemes, however, the bore-hole information is not adequate for the purpose of this study and does not provide a complete morphological section across the gully. Further drifts often obscure the surface outcrop. Where observed, both col-gully walls had a slope of more than $30^{\circ}$ from the horizontal.

The col-gully opens and deepens northward, its floor falling from $c .65 \mathrm{~m}$ to $c .50 \mathrm{~m}$ O.D. (Fig. 4). It opens northward, the east wall being orientated at $25^{\circ} \mathrm{N}$., the west wall at $355^{\circ} \mathrm{N}$. Morphologically, the col-gully "hangs" above the adjacent alluvial lowlands, which lie at about $7 \mathrm{~m} \mathrm{O.D.}$

\section{INTERPRETATIONS}

Two general interpretations may be advanced: (a) Triassic origin and (b) Pleistocene origin.

\section{Triassic interpretations}

Triassic and conglomeratic deposits (Dolomitic Conglomerate) filling hollows and gullies in the Carboniferous Limestone are well known in the Bristol district (Kellaway and Welch, 1948). The Court Hill col-gully and its associated deposits, however, cannot be the result of Permo-Triassic processes as Cretaceous rock types and Cretaceous and Jurassic fossils are present in the deposits.

The East Glevedon Gap is shown on Geological Sheet 264 to be floored by Keuper Marl (Triassic). Hawkins (1972), however, reported that a bore hole in the middle of the valley failed to prove the presence of Keuper Marl below the post-Cretaceous gravels and sands, which he interpreted as being Quaternary.

\section{Pleistocene interpretations}

The drift deposits. There is considerable evidence to suggest the col-gully and its infill deposits are Pleistocene in age.

Unit 6 . The stratigraphical relationship of the red sandy silt (loam) covering all lower drifts and bedrock on Failand Ridge suggests it is aeolian in origin. This conclusion is supported by mineralogical and particle-size investigations, which have shown it is an exposure of part of the almost continuous blanket of periglacial cover sand which mantles many of the Carboniferous Limestone hills south of Bristol (Findlay, rg65; Colbourne and others, 1974; Gilbertson and Hawkins, 1974, in press).

Unit 5. The following lines of evidence indicate this cobble- and boulder-rich diamicton is a till and not a soliflucted Triassic deposit into which cobbles and boulders of local and non-local provenance have been incorporated by frost processes. It is unsorted, unbedded and has a stiff red sandy silt matrix binding together substantial boulders (many about $0.5 \mathrm{~m}$ in diameter) and cobbles of Devonian, Carboniferous, and Cretaceous rock types distributed fairly uniformly through the deposit. Although this diamicton is dependent for its red fine fraction upon incorporation of Keuper Marl, it occurs above the height of in situ or soliflucted Triassic deposits on this part of Failand Ridge. In situ Devonian, Jurassic, and Cretaceous rock types do not occur in the immediate area. 
GLACIAL DEPOSITS AT CLEVEDON, ENGLAND

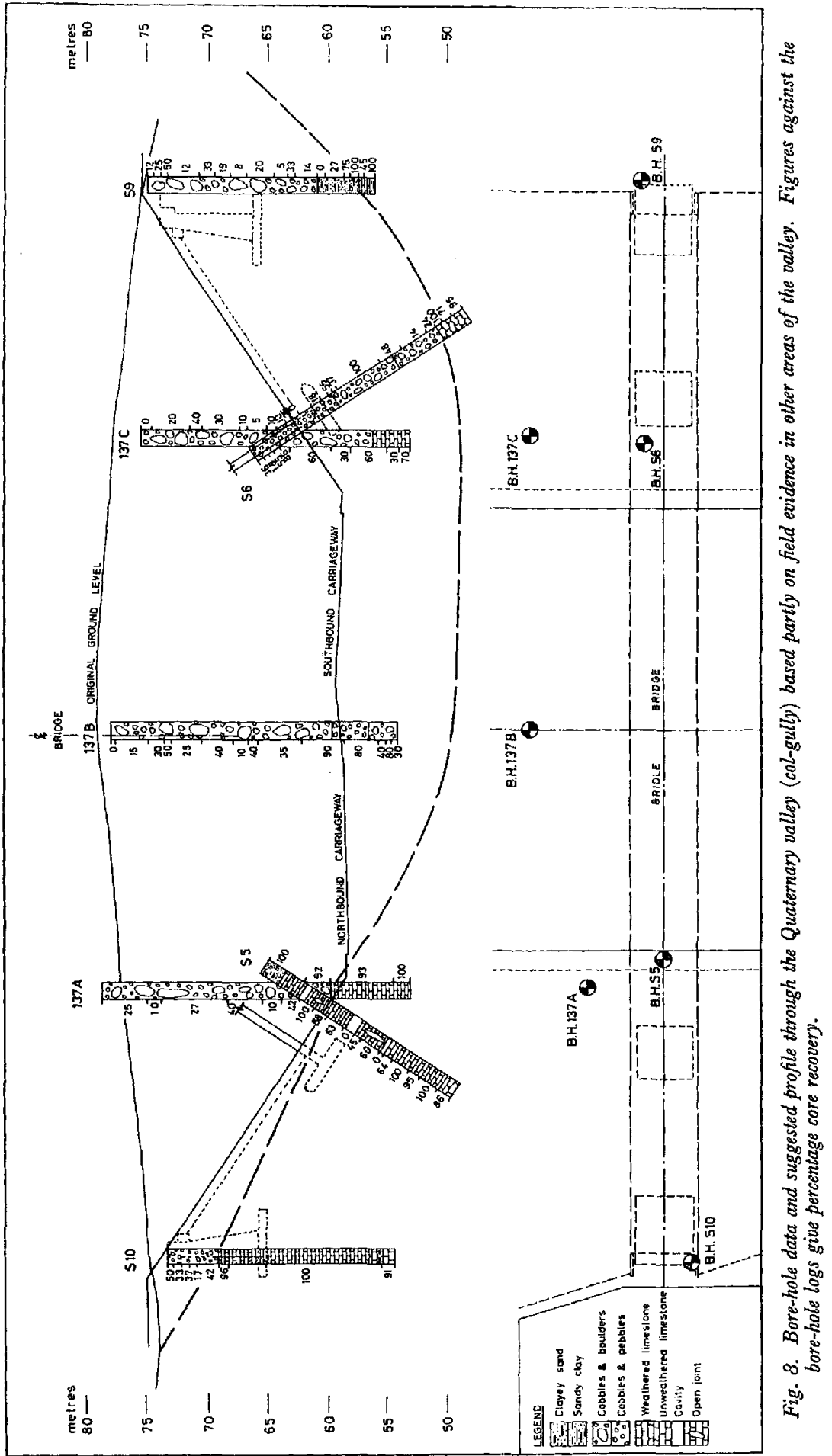


Unit 4. The stratigraphical relationships of the layers of clay/silt with cobbles and boulders, overlying or replacing the gravel, cobble, or boulder bands of units $3^{-2}$ suggest these drifts have slid or slumped down the developing drift surfaces and, as such, have the characteristics of flow tills.

Units $3-2$. The steep $\left(3^{\circ}-37^{\circ}\right)$ dip, rapid changes in clast size (gravel to boulders of up to $8 \mathrm{Mg}$ ), good to poor sorting and rounding are, taken together, properties characteristic of ice-contact deposits (Flint, I97I). In the topographic context of the Court Hill col-gully, the steeply dipping bands of coarse and fine material generally washed free of fines (units $3^{-2}$ ) can only be satisfactorily explained as the result of large fluctuations in discharge down a steep ice-marginal slope. Seasonal or even diurnal variations in temperature may be indicated.

The large cavities (unit 7) present in the most boulder-rich deposits in the south of the gully only seem explicable if considered as voids left by the melting of ice blocks incorporated in the sediment; in this case the cementing of the boulders at point contact by a calcitic cement must have taken place rapidly, since few signs of wall and roof collapse have been seen in the voids inspected. This cement may have been derived from the solution of calcareous rocks-Carboniferous, Jurassic, or Cretaceous-or perhaps from shells originally derived from the floor of the Bristol Ghannel or Irish Sea area.

Unit $I$. These gritty cross-laminated sands with topsets, foresets, and bottomsets are obviously waterlain. Their interdigitation with ice-contact sediments suggests they are ice-marginal in origin and may be referred to as "glacio-lacustrine". There is no indication of wave or current activity in the sedimentary structures. The thin silt bands indicate that on occasion the water body became sufficiently quiet for fines to settle out on the bottom. A water level of at least $75 \mathrm{~m}$ o.D. occurred at one period. The dimensions of the sand body indicate a small lake at least $5^{\circ} \mathrm{m}$ by $15^{\circ} \mathrm{m}$ in size must have been present. The physiography (Figs 1 and 2) of the area indicates that a lake or any other body of water can only have occurred in one of two ways: either the Vale of Gordano (Fig. I) was occupied by an ice mass, in which case the water body had a surface area measurable in thousands of square metres; or alternatively, if the Vale of Gordano was ice-free, the normal drainage of the area must have been obstructed by an ice mass stretching across and blocking drainage in the Severn Estuary. This would have produced pro-glacial Lake Maw (Mitchell, 1960, 1972), measurable in hundreds of square kilometres.

Composition. The precise provenance of the rock types remains uncertain since it is possible to conceive that the former high-level drainage networks, drainage captures and subsequent re-cycling patterns discussed by Frey (1975) could all bring the various rock types and fossils to the area. Nevertheless, there are no known remanie deposits in the area which would yield either the volume of material or the individual clast sizes found at Court Hill.

Four rock types merit particular attention. Coal Measures sandstone is conspicuously lacking in the drift. This is surprising in view of its outcrop immediately north of the Col and suggests the major area of derivation was to the south of the line of Failand Ridge. Greensand cherts are common in most drifts of the west of England but Cretaceous flints are much less common. The cherts characterize the drifts of the Bristol district, although the area is well separated from the Greensand scarp. Unlike the siliceous cherts and flints, the calcareous Cretaceous micro-fossils seem unlikely to resist multiple re-cycling from higher surfaces and drainage networks. Consequently, there appear good grounds for regarding Greensand chert, Chalk flints and Gretaceous micro-fossils in the Bristol area as, at least in part, resulting from an introduction by ice sheets. Recent investigations of the submarine geology of the sea bed west of Bristol (Donovan and others, I961, 1970; Curry and others, I967; Hamilton and Blundell, I97o; Lloyd and others, r973) lend support to the hypothesis advanced in Gilbertson and Hawkins (in press) that, as an ice sheet moved into the Somerset lowlands from the Bristol 
Channel and Celtic Sea area, it would have incorporated all the rock types found at Kenn and now at Court Hill.

The col-gully and glacial sequence at Court Hill. In view of the topographic and geological setting of the Court Hill Col discussed previously, it is difficult to conceive of any process, other than glacial, which would provide a sufficient volume of water to erode the col-gully at the appropriate altitude. This observation is supported by the morphological and dimensional similarities between the Court Hill col-gully and the col-gullies originally described from Scandinavia by Mannerfelt ( 1945 ) and from Britain by Derbyshire ( 1961 ) and Clapperton (1968). These landforms have been identified with erosion by glacial melt waters. The extent to which the northern exit of the Court Hill col-gully "hangs" above the Vale of Gordano suggests the vale was occupied by water, and/or ice, to a height of approximately $65 \mathrm{~m}$ o.D., at the same time as the col-gully was being eroded. If this were not the case, it would be anticipated that the gradient of the col-gully floor would merge with the form of the hillslope or floor of the Vale. Irrefutable evidence for the occupation of the vale by ice sheets as opposed to water is as yet lacking but several authors have suggested that its Pleistocene drifts with erratics, its surprisingly large buried channel system and the anomalously routed valleys on its hillslopes may well be explained as the result of the former downwasting ice mass (Hawkins, [1968], 1972; Hawkins and Kellaway, 197 I Colbourne and others, 1974; Gilbertson and Hawkins, 1974, in press). Occupation of the Vale of Gordano by ice would also explain the water body in which the gritty sands (unit I) collected as a comparatively small ice-marginal lake trapped against the north flank of Failand Ridge rather than as a pro-glacial lake of immense dimensions.

It seems probable that the erosion of the col-gully represents part of the same glacial sequence as the glaciogenic deposits occupying the Col; certainly no evidence has been found to the contrary.

The precise nature of the melt-water processes responsible for the erosion of the col-gully is open to debate and its elucidation depends upon the interpretation of the glacial sequence at the Col. It is clear from the stratigraphy that the main morphology of the col-gully was already largely in existence when the infilling ice-contact and glacio-lacustrine deposits collected within it. The col-gully might similarly represent erosion in a pro-glacial environment. An ice sheet advancing into the Yeo Lowlands might be anticipated to impound a series of small lakes as it impinged against Failand Ridge. Eventual overflow from such a small lake might be expected to erode a gully through the lowest point of the Col. Local advance and consequent elevation of the ice surfaces may have caused the edge of the ice sheet to enter the gully and cause the ice-contact deposits to accumulate within it. Subsequent continued advance may have resulted in the ice sheet over-riding the Col, with the till (unit 5 ) being deposited upon further advance, or later downwasting.

An alternative explanation can be envisaged (see Fig. 9) which would relate the col-gully and associated infill deposits to a downwasting, as opposed to an advancing ice mass. Clapperton ( 1968 ) has described how during the downwasting of an ice mass the increasing influence of the underlying relief might cause en- and sub-glacial drainage progressively to migrate towards, concentrate in and erode into areas where cols occurred in buried topographic ridges beneath the ice. This process would also explain satisfactorily the form and location of the Court Hill col-gully. Tills may have started to collect on the rock surfaces upon emergence of the relief above the ice mass, and the process envisaged by Mannerfelt (1945) might ensue. Surface water draining both from the emergent divides and ice masses may be added to pre-existing sub- and englacial drainage, perhaps greatly enlarging the col-gully. Ice-contact deposits then collected in the southern part of the col as the ice mass melted. A similar downwasting ice mass in the Vale of Gordano may have held up the small lake in which the gritty sand (unit I) collected. The overlying till (unit 5) might owe its position to final movements of debris-rich material from the ice surface and adjacent hill- 


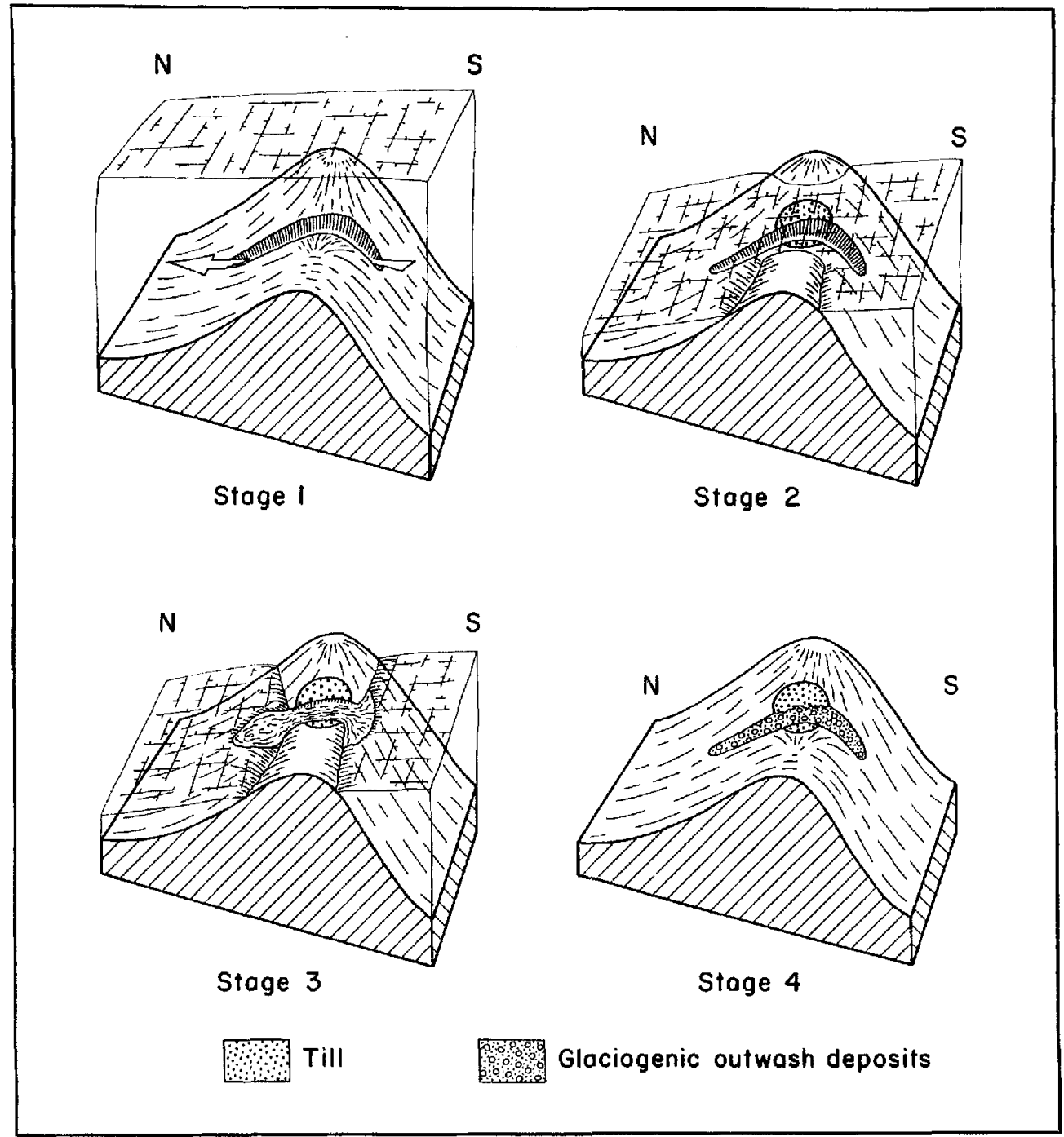

Fig. 9. Suggested stages in the development of the col-gully.

slopes. Extensive modification of unit 5 by quarrying, compaction, and grading renders as unreliable a verification by stone-orientation studies.

There is insufficient evidence available as yet to establish conclusively which of these two types of interpretation (or indeed the many possible combinations between them) actually occurred. However, the limited evidence available at present suggests the downwasting concept explains more features and presents fewer difficulties. For example, it would be surprising if an advancing ice sheet had not later gouged or flushed out previously deposited glaciogenic deposits in the col-gully, even if they were in a frozen state. The downwasting icemass concept would more readily provide an area of ponded water in the north of the col-gully at the same time as water and sediment were discharging into it from the higher ice mass to the south. An advancing ice shect, however, entering the Vale of Gordano, might be anticipated to arrive after the ice from the Yeo Basin had completely crossed the col, hence too late to support a small ice-marginal lake in the vicinity of the Col. This is assuming that the hill 
ranges which almost encircle the Vale of Gordano (Fig. I) were sufficiently high to have significantly delayed entry of an ice mass into the Vale.

Downwasting would also explain more satisfactorily the functional relationships between the cols and through-valleys of Failand Ridge at the time of glaciation. A logical downwasting sequence would suggest the progressive abandonment by sub-, en- and supraglacial meltwater drainage of the higher cols in favour of either the adjacent much lower and deeper East Clevedon Gap (Fig. I) with its rock floor at least $-6 \mathrm{~m}$ o.D., or through the buried channel system of the Yeo Lowlands to the south, described by Gilbertson and Hawkins (in press). If ice-sheet advance is invoked to explain the glacial sequence, it is difficult to understand why a pro-glacial lake, whose overflow was of sufficient dimensions to erode the Court Hill col-gully, should not have initially used, eroded, and later continued to overflow through the adjacent East Glevedon Gap. If the impounded ice-marginal lake was of such small dimensions that it could only overflow through the Col, it is unclear why such a large col-gully should have been eroded.

Although far from conclusive, the available evidence indicates the col-gully and glacial sequence are currently best interpreted in terms of a downwasting ice mass. The dimensions of the col-gully point to the importance of sub- and englacial drainage (perhaps aided by supraglacial drainage) in interpreting the gorge and valley landforms of the area.

\section{DATING}

Unfortunately, neither biogenic deposits nor weathering layers have been found which would have facilitated dating of the Court Hill site. Several lines of evidence suggest the glaciogenic features may be provisionally regarded as Wolstonian or older in age. First, they pre-date one phase of aeolian periglacial activity which is almost certainly of Devensian age. All the presently published evidence indicates that Devensian ice sheets did not cross the Bristol Channel/Severn Estuary into Somerset and Avon (Bowen, 1970, I973; Gilbertson and Hawkins, in press; Gilbertson, unpublished). At nearby Kenn (Fig. I), glaciogenic deposits of a very similar composition to those at Court Hill have been identified as probably Wolstonian in age, since they are overlain by interglacial deposits referred to the Ipswichian interglacial (Gilbertson and Hawkins, in press).

\section{LiMITS OF GLAGIATION}

The Quaternary deposits and landforms in Court Hill Col demonstrate that a considerable thickness of ice entered the coastal lowlands east of the Severn Estuary. The very localized survival of glacial deposits in this area makes reconstructing the limits of this glaciation difficult. Glacial drifts, provisionally attributed to the Wolstonian ice sheet, have been located in the Yeo Lowlands at Kenn and Yatton (Gilbertson and Hawkins, in press) and Churchill (Hawkins, 1972 ). The origins and ages of the drifts on the hill summits at about $100 \mathrm{~m}$ in the Bristol area (Davies and Fry, 1929) are more difficult to establish because of the sparsity of exposures. They are characterized by the presence of Greensand chert and Chalk flints, non-local rock types which are very common in the glacial deposits at Court Hill and Kenn. Drift deposits at Moat House Farm, Ashton Park, Leigh Wood, and Portishead Down reaching up to $122 \mathrm{~m}$ o.D. (Fig. I) have been examined recently and interpreted as glacial in origin (Colbourne and others, 1974). This explanation is supported by the observation that the ice responsible for the glaciogenic deposits on the Col slopes at Court Hill must have attained a greater elevation than the $80 \mathrm{~m}$ o.D. reached by the "till" (unit 5 ). Consequently, it may be suggested that these high-level drifts may represent remanié tills or outwash deposits, and hence give a general indication of the area likely to have been occupied by ice sheets.

These observations support a glacial interpretation of many of the valleys and gullies of the Bristol district which, like the Court Hill col-gully, have anomalous relationships with both 
topography and geology. Typical are the col-gullies or valleys at Tickenham Hill, Cadbury Hill, Henbury, Providence and Rickford, which Hawkins and Kellaway (197I) and Hawkins (1972) suggested were only explicable as the results of erosion by glacial melt water. Their suggestion is supported by the nature and elevation of the find at Court Hill Col. As yet, no deposits or landforms are known in the area south-east of Bristol which would help establish the landward limit of glaciation. Since, however, there is clear evidence that the surface ice sheet reached at least $85 \mathrm{~m}$ o.D., and good reason to believe that on Failand Ridge it reached more than $120 \mathrm{~m}$ O.D. (Hawkins, 1972; Colbourne and others, 1974), there is every reason to believe that ice of this thickness would only have been stopped on its landward advance by hill masses such as the Mendips (250-300 m o.D.), Broadfield Down ( $180 \mathrm{~m}$ o.D.), Dundry (200 $\mathrm{m} \mathrm{O.D.)}$ and the west-facing scarp of the Cotswolds.

\section{Drainage diversions}

The penetration of an ice sheet about $85-125 \mathrm{~m}$ thick into the Yeo Lowlands is likely to have been impeded by the constriction of the steep-sided vale in the Ubley-West Harptree district, giving credence to the views of Hawkins and Kellaway (1971) and Hawkins (1972) that the River Chew may have abandoned a seaward route through the lowlands and adopted a new easterly course as a result of the damming of the normal surface drainage (see Frey (1975) for an alternative view).

There is evidence for the former existence of small ice-marginal lakes in the area at Court Hill and Kenn, but as yet no evidence of a lake the size of Lake Maw. Indeed, the Severnside area may have been occupied by ice rather than water, introducing the erratic-rich drifts beneath the Severnside Lowlands, described by Morgan (1887).

Whilst this discussion has not conclusively established that the Avon Gorge at Clifton was formed by sub-, en- or supraglacially draining melt water, there now appears to be good circumstantial evidence indicating that it at least acted as a melt-water drainage channel.

Erratic-rich drifts and gorges on the high-level plateau surfaces of the Cotswolds above Bath, and on the Mendips, have been identified as the result of a much older and more widespread glaciation (Hawkins and Kellaway, 1971; Kellaway, I971 ; Kellaway and others, I971; Hawkins, 1972). This older glacial episode is at the moment distinguished in the Bristol area on the basis of the topographic location of its drifts. These lie on hill summits at and above $200 \mathrm{~m}$, whereas the drifts tentatively associated with the Kenn and the Court Hill glaciation appear to lie in broad valleys or on plateaux eroded into and well below the higher drift-covered surfaces.

\section{Conclusions}

The Pleistocene deposits and landforms recently exposed in excavations at Court Hill Col demonstrate that an ice sheet penetrated into the lowlands east of the Severn Estuary, advancing inland from the Bristol Channel and Severn Estuary area.

The surface elevation of the ice sheet at Court Hill was at one stage at or greater than $85 \mathrm{~m}$ O.D. Other local evidence indicates an altitude of at least $125 \mathrm{~m}$. The ice probably occupied most of the western lowlands of Avon County to Broadfield Down, Dundry Hill, and the Mendips, although there is at present no evidence for the eastern extent, which may have been at the Cotswolds scarp. On decay of the ice sheet, sub- and englacial melt waters' flow became concentrated in cols in the underlying relief where it eroded large col-gullies into the base of the pre-existing cols.

Several col-gullies, other than the best known at Court Hill, occur in Failand Ridge above Tickenham and Nailsea. Through-valleys such as the East Clevedon Gap, Rickford Valley, and Henbury Gap are attributable to sub- and englacial melt-water erosion. It is probable also that a significant part of the buried channel system of the coastal lowlands was similarly 
eroded by subglacial melt-water drainage. There is little evidence for the former existence of surface glacial melt-water spillways joining large glacially impounded lakes as proposed by Harmer (1907). Reversals of surface drainage by ice damming were caused in the Chew Valley. The Avon Gorge probably functioned, if indeed it did not originate, as a melt-water channel. On downwasting of the ice at Court Hill, stratified ice-marginal deposits accumulated on an ice slope leading into a small ice-marginal lake.

Apart from the nearby village of Kenn, other drift deposits in the area are poorly exposed. Future major excavations, however, may well reveal glacial deposits of the dimensions of those at Court Hill. The deposits and landforms at Court Hill, Kenn and below approximately I $5^{\circ} \mathrm{m}$ are provisionally referred to as the Wolstonian or Anglian stage of the Pleistocene. The Devensian stage at Court Hill, and in much of the western part of Avon County, is characterized by the deposition of a blanket layer of periglacial cover sands. All these glacial and periglacial features are probably younger than another set of possible glacial deposits and landforms which occur at and above $200 \mathrm{~m}$ O.D. on parts of the Cotswold and Mendip Hills.

\section{AGKNOWLEDGEMENTS}

The authors are grateful to Freeman Fox and Partners, especially M. Lewis and C. Morgan, for allowing free access to the site and for supplying drawings and levels used in the preparation of this paper; to Dr G. A. Kellaway for very helpful discussions; to Jean Bees for preparing the line illustrations and R. Godwin for the photographs. The work was carried out during the period of a N.E.R.C. research grant.

MS. received I7 May 1977

\section{REFERENGES}

Bowen, D, Q. 1970. South-east and central South Wales. (In Lewis, C. A., ed. The glaciations of Wales and adjoining regions. London, Longman Group Ltd., p. 197-227.)

Bowen, D. Q. 1973. The Pleistocene succession of the Irish Sea. Proceedings of the Geologists' Association, Vol. 84, No. 3, p. 249-72.

Clapperton, C. M. 1968. Channels formed by the superimposition of glacial meltwater streams, with special reference to the east Cheviot Hills, north-east England. Geografiska Annaler, Vol. 50A, No. 4, p. 207-20.

Colbourne, G. J., and others. I 974 . Temporary drift exposures on the Failand ridge, by G. J. Colbourne, D. D. Gilbertson and A. B. Hawkins. Proceedings of the Bristol Naturalists' Society, Vol. 33, Pt. I, p. 91-97.

Gurry, D., and others. 1967 . Upper chalk from the sea-bed, south of Cork, Eire, by D. Curry, F. Gray, D. Hamilton and A. J. Smith. Proceedings of the Geological Saciety of London, No. 1640, p. 134-36.

Davies, J. A., and Fry, T. R. I92g. Notes on the gravel terraces of the Bristol Avon. Proceedings of the University of Bristol Speleological Society, Vol. 3, No. 3, p. $162-72$.

Derbyshire, E. I 661 . Sub-glacial col gullies and the deglaciation of the north-east Cheviots. Institute of British Geographers. Transactions, No. 29, p. $3 \mathrm{I}-46$.

Donovan, D. T. I 969 . Geomorphology and hydrology of the central Mendips. Proceedings of the University of Bristol Speleological Society, Vol. 12 , No. I, p. 63-74.

Donovan, D. T., and others. I 961 . Geology of the floor of the Bristol Channel, by D. T. Donovan, R. J. G. Savage, A. H. Stride and A. R. Stubbs. Nature, Vol. I69, No. 4758, p. 51-52.

Donovan, D. T., and others. 1971. Geology of the Bristol Channel, [by] D. T. Donovan, A. J. Lloyd and A. H. Stride. Proceedings of the Geological Society of London, No. 1664, p. 294-95.

Findlay, D. C. 1965 . The soils of the Mendip district of Somerset (sheets 279 and 280). Memoirs of the Soil Survey of Great Britain: England and Wales.

Flint, R. F. 1971. Glacial and Quaternary geology. New York, etc., John Wiley and Sons.

Frey, A. E. 1975. River patterns in the Bristol district. (In Peel, R., and others, ed. Processes in physical and human geography, edited by R. Peel, M. Chisholm and P. Haggett. London, Heinemann Educational Books, p. 148-65.)

Gilbertson, D. D. Unpublished. The Pleistocene succession in the coastal lowlands of Somerset. [Ph.D. thesis, University of Bristol, 1974.]

Gilbertson, D. D., and Hawkins, A. B. I974. The Pleistocene deposits and landforms at Holly Lane, Clevedon, north Somerset. Proceedings of the University of Bristol Speleological Society, Vol. 13, No. 3, p. 349-6o.

Gilbertson, D. D., and Hawkins, A. B. In press. The Pleistocene succession at Kenn, north Somerset. Bulletin of the Geological Survey of Great Britain, No. 66. 
Hamilton, D., and Blundell, D. J. 1971. Submarine geology of the approaches to the Bristol Channel. Proceedings of the Geological Society of London, No. 1664, p. 297-300.

Harmer, F. W. I907. On the origin of certain cañon-like valleys associated with lake-like areas of depression. Quarterly Journal of the Geological Society of London, Vol. 63 , No. 252, p. 470-5 I4.

Hawkins, A. B. [1968.] The geology of the Portbury area. Proceedings of the Bristol Naturalists' Society, Vol. 31 , Pt. 4,1967, p. $421-28$.

Hawkins, A. B. 1972. Some gorges of the Bristol district. Proceedings of the Bristol Naturalists' Society, Vol. 32, Pt. 2, p. $167-85$.

Hawkins, A. B., and Kellaway, G. A. 1971. Field meeting at Bristol and Bath with special reference to new evidence of glaciation. Proceedings of the Geologists' Association, Vol. 82, Pt. 2, p. 267-92.

Kellaway, G. A. 197I. Glaciation and the stones of Stonehenge. Nature, Vol. 233, No. 5314, p. 30-35.

Kellaway, G. A., and Welch, F. B. A. 1948. Bristol and Gloucester district. Second edition. London, His Majesty's Stationery Office. (G.B. Geological Survcy and Museum. British Regional Geology.)

Kellaway, G. A., and others. 1971. The development of some Pleistocene structures in the Cotswolds and upper Thames basin, by G. A. Kellaway, A. Horton and E. G. Poole. Bulletin of the Geological Survey of Great Britain, No. 37 , p. $1-28$.

Lloyd, A. J., and others. 1973. The geology of the Bristol Channel floor, by A. J. Lloyd, R. J. G. Savage, A. H. Stride and D. T. Donovan. Philosophical Transactions of the Royal Society of London, Ser. A, Vol. 274, No. I244, p. $595-626$.

Mannerfelt, C. M. 1945. Några glacialmorfologiska formelement och deras vittnesbörd om inlandsisens avsmältrningsmekanik i svensk och norsk fjällterräng. Geografiska Annaler, Arg. 27, Ht. I-2, p. I-239.

Mitchell, G. F. 1960 . The Pleistocene history of the Irish Sea. Advancement of Science, Vol. 17, No. 68, p. 313-25.

Mitchell, G. F. I 972. The Plcistocene history of the Irish Sea: second approximation. Scientific Proceedings of the Royal Dublin Society, Ser. A, Vol. 4, No. 13, p. 18 $1-99$.

Mitchell, G. F., and others. 1973. A correlation of Quaternary deposits in the British Isles, [by] G. F. Mitchell, L. F. Penny, F. W. Shotton and R. G. West. Geological Society of London. Special Report, No. 4.

Morgan, G. L. 1887 . The Severn Tunnel section. Proceedings of the Bristol Naturalists' Society, Vol. 5, Engineering Section, p. $82-94$.

Trimmer, J. 1853 . On the southern termination of the erratic tertiaries; and on the remains of a bed of gravel on the summit of Clevedon Down, Somersetshire. Quarterly Journal of the Geological Society of London, Vol. 9, Pt. I, p. $282-86$

Vink, A. P. A. Unpublished. Contribution to the knowledge of loess and coversands, in particular of south east Veluwe. [Ph.D. thesis, University of Wageningen, Netherlands, 1949.] 